\title{
Review
}

\section{Partisanship and political liberalism in diverse societies}

\author{
Matteo Bonotti \\ Oxford University Press, Oxford, 2017, viii+197 pp., ISBN: 978-0-19- \\ 873950-0
}

Contemporary Political Theory (2018) 17, S256-S259. https://doi.org/10.1057/s41296017-0169-0; published online 17 November 2017

Political theorists have for a long time shunned political parties. This has changed in the last decade or so, and the body of normative-theoretical work on the topic is steadily growing. So far, three major books by leading theorists have emerged $-O n$ the Side of the Angels by Rosenblum (2008); The Promise of Party in a Polarized Age by Muirhead (2014); and The Meaning of Partisanship by White and Ypi (2016). What these intellectually ambitious works share in common is a commitment to the idea that parties are not a necessary evil but an indispensable feature of democracy.

Matteo Bonotti's Partisanship and Political Liberalism in Diverse Societies, the latest addition to the normative-theoretical literature on parties, starts from the same premise - but otherwise the book differs quite a bit from previous scholarship on the topic. Its concern is not so much with defending partisanship or exploring its distinctive features, but with establishing the place of parties in John Rawls's influential philosophy of political liberalism. From the outset, Bonotti is unequivocal about his ambitions: although the book is no doubt animated by a general interest in the theoretical study of parties and partisanship, its central goal is to rescue 'Rawls's theory from the widespread accusation that it is inhospitable to real-world politics, and especially to party politics' (p. 175).

The book touches on a wide range of issues, including free speech, religion in the public sphere, and electoral systems, relating these themes creatively to Rawls's work and the topic of parties. The book's centrepiece, however, is Bonotti's attempt to show that partisanship is fully compatible with Rawls's conception of public reason. To achieve this, Bonotti works with admirable precision through all the complexities inherent in Rawls's understanding of public reason, concluding that 'there is in fact a correspondence between the demands of Rawls's ideal of public reason and those of partisanship, when the latter is intended as a normative ideal' (p. 63). This may not be entirely surprising to those familiar with recent normative-theoretical studies of partisanship, for there seems to be some

(C) 2017 Macmillan Publishers Ltd., part of Springer Nature. 1470-8914 Contemporary Political Theory Vol. 17, S4, S256-S259 www.palgrave.com/journals 
agreement in this body of work that such a correspondence exists, but it is certainly not a widely held view in contemporary political theory.

More particularly, Bonotti argues that the demands of public reason correspond to the demands of partisanship because 'Presenting partial values and demands in a way that takes into account general ends and the common good ... is the distinctive normative attribute of partisanship' (p. 105). The ideal partisan, in other words, is an ideal public deliberator as envisaged by Rawls. This idea is doing a considerable amount of work in Bonotti's book, resolving all sorts of tensions one might expect that exist between public reason and partisanship; thus, to evaluate whether Bonotti's project succeeds, it is worthwhile looking a bit more closely at it.

One issue many a reader will worry about is whether Bonotti's conception of partisanship bears any resemblance to how partisanship tends to look in 'real-world politics'. For if the sort of partisanship Bonotti defends exists only in an ideal world that one might hope to live in, then it is doubtful whether the book's aim of grounding Rawls's political liberalism in political reality can be achieved.

The first thing to note in clarifying this issue is that the normative conception of partisanship Bonotti employs is rooted in much older treatments of the topic. It harks back to the pioneering work of Edmund Burke, who is something like the patron saint of recent normative party scholarship; however, Bonotti also mentions thinkers as different as the fourteenth-century jurist Bartolo da Sassoferrato and the twentieth-century political scientist Giovanni Sartori to make his case. What is barely acknowledged along the way is that many of those earlier scholars understood their conceptions of party not so much as purely normative conceptions, but as descriptions of empirical reality. To be sure, they often had an evaluative purpose - for instance, to distinguish public-minded (and hence desirable) parties from sectarian (and hence undesirable) 'factions'. But there can be no doubt that they were not only intended to describe how things should be, but also how they are.

Bonotti generally avoids making the more ambitious claim that his conception of partisanship may well have empirical resonance, emphasising instead (citing White and Ypi approvingly) that we should resist the 'empiricization of the idea of the party' (p. 105) - a proposition that is predicated on the contestable view that the only plausible empirical conception of parties is one that sees them as purely selfinterested power maximisers. In so doing, however, Bonotti also makes it look as though partisans' 'compliance with the normative demands of partisanship' ( $\mathrm{p}$. 118), and thus their compliance with the demands of public reason, is purely hypothetical.

Possibly as a result of resorting to hypotheticals here, the book never systematically engages with the crucial question of why real-world partisans would be inclined to present 'partial values and demands in a way that takes into account general ends and the common good' in the first place. This question is by no means trivial. It is essential to understand whether Bonotti's account can

(C) 2017 Macmillan Publishers Ltd., part of Springer Nature. 1470-8914 Contemporary Political Theory Vol. 17, S4, S256-S259 S257 
ultimately convince, for, again, many readers will likely find the proposed ideal of partisanship objectionably unworldly.

So far as I can see, there are at least three possible reasons why partisans would present their partial commitments in terms of the common good. They may (a) be intrinsically motivated due to a sincere concern for the common good; (b) be extrinsically motivated by the fear of social sanction due to widely accepted norms concerning how partisanship or political speech ought to look; or (c) be extrinsically motivated by the dynamics of party competition to present their proposals in terms of the common good.

A close reading of Partisanship and Political Liberalism in Diverse Societies provides some interesting clues as to what Bonotti thinks about the matter. In some of the more empirical passages of the chapter on 'Parties and the Overlapping Consensus', for example, Bonotti suggests (c) as a possible explanation, arguing that "parties that are initially solely (or mainly) focused on religious issues ... must broaden their range of policy proposals in order to become credible in the marketplace of party politics' (p. 121). This is a very plausible proposition, and one that strongly supports Bonotti's larger case. It chimes with Sartori's argument that '[e]ven if the party politician is motivated by crude self-interest, his behaviour must depart - if the constraints of the system [of electoral competition] are operative from the motivation' (Sartori, 2005 [1976], p. 22). Yet Bonotti does not engage much with the deeper mechanisms at work to drive his point home. This seems, at least to this reviewer, like a missed opportunity - especially in light of the book's stated aim to bring Rawls's political liberalism closer to real-world politics.

Nothwithstanding the fact that Bonotti's book would have profited from a stronger focus on the empirical dimensions of partisanship, and that some idealising moves should have arguably been resisted, it is important to note that it still provides an immensely valuable addition to the new literature on the political theory of parties and partisanship. One of the book's most important contributions is that it - more than any other recent book on the topic - renders the subject of political parties and partisanship 'digestible' for mainstream political theory. This is not only because it shows how an analysis of parties is directly relevant to numerous on-going debates in the field, but also because it is generally much more faithful to the Rawlsian/post-Rawlsian paradigm that pervades contemporary political theory than previous works, thus speaking a language that will prove accessible for a very wide readership.

In the end, Partisanship and Political Liberalism in Diverse Societies is arguably the most theoretically conservative book on the topic of parties and partisanship that has been written so far - but for that very reason, it might well become the most influential and widely discussed one. It presents an invitation to mainstream political theory to take parties seriously as an object of study, convincingly showing that there are really no good reasons for political theorists of the Rawlsian kind to shy away from parties. Although a firmer integration of 
empirical and normative reasoning would have made the book even more persuasive, this is no doubt a real contribution.

\section{References}

Muirhead, R. (2014). The Promise of Party in a Polarized Age. Cambridge, MA: Harvard University Press.

Rosenblum, N. L. (2008). On the Side of the Angels: An Appreciation of Parties and Partisanship. Princeton, NJ: Princeton University Press.

Sartori, G. (2005) [1976]. Parties and Party Systems: A Framework for Analysis. Colchester: ECPR Press.

White, J., \& Ypi, L. (2016). The Meaning of Partisanship. Oxford: Oxford University Press.

Fabio Wolkenstein

Aarhus University, 8000 Aarhus C, Denmark wolkenstein@ps.au.dk 